\title{
ANALISIS KESALAHAN SISWA DALAM MENYELESAIKAN SOAL PEMAHAMAN KONSEP MATEMATIKA SEKOLAH DASAR PADA MATERI BANGUN DATAR
}

\author{
Melisari $^{1}$, Asri Septihani ${ }^{2}$ Arpin Chronika ${ }^{3}$, Bunga Permaganti ${ }^{4}$, Yeti Jumiati ${ }^{5}$, Nelly Fitriani ${ }^{6}$ \\ 1.2.3.4.5.6 IKIP Siliwangi, J1 Terusan Jenderal Sudirman Cimahi 40526 \\ melisholehah@gmail.com
}

\begin{abstract}
This study aims to analyze the students' mistakes in solving the problem of understanding the ability of elementary school mathematical concepts on planes. Assessment on the aspect of understanding the concept aims to find out how far the ability of students in the matter of understanding the concept of mathematics with indicators a) Restate a concept; b) Classifying objects according to certain properties according to the concept; c) Give examples and not examples of concepts; d) Presenting concepts in various forms of mathematical representation; e) Developing the necessary conditions or sufficient conditions of a concept; f) Using, utilizing, and choosing certain procedures or operations; g) Apply concepts or algorithms in mathematical problem solving. This study is a qualitative research with case studies to analyze the understanding of elementary school students' mathematical concepts in solving problems regarding planes. In determining the subject of this study using a purposive sampling technique by selecting and sorting subjects that meet predetermined criteria. The subjects of this study were all fifth grade students of SDS Pangkalan Subdistrict of Babakan Ciparay, totaling 17 people. The instrument in this study was a matter of tests of understanding the mathematical concepts of planes. The results showed that most students have low mathematical concept comprehension ability in the material of flat build and errors made in working on problems based on Newman's analysis mostly lie in the understanding of problems which is as much as $41.17 \%$.
\end{abstract}

Keywords: Student Error, Planes, Understanding Concepts

\begin{abstract}
Abstrak
Penelitian ini bertujuan untuk menganalisis kesalahan siswa dalam menyelesaikan soal kemampuan pemahaman konsep matematika sekolah dasar pada materi bangun datar. Penilaian pada aspek pemahaman konsep bertujuan untuk mengetahui sejaiuh mana kemampuan siswa dalam soal pemahaman konsep metematika dengan indikator a) Menyatakan ulang sebuah konsep; b) Mengklasifikasikan objek-objek menurut sifat-sifat tertentu sesuai dengan konsepnya; c) Memberi contoh dan bukan contoh dari konsep; d) Menyajikan konsep dalam berbagai bentuk representasi matematis; e) Mengembangkan syarat perlu atau syarat cukup suatu konsep; f) Menggunakan,memanfaatkan,dan memilih prosedur atau operasi tertentu; g) Mengaplikasikan konsep atau algoritma dalam pemecahan masalah matematis. Penelitian ini merupakan penelitian kualitatif dengan studi kasus untuk menganalisis pemahaman konsep matematika siswa sekolah dasar dalam menyelesaiakan soal mengenai bangun datar. Dalam menentukan subjek penelitian ini menggunakan teknik purposive sampling dengan memilih dan memilah subjek yang memenuhi kriteria yang telah ditentukan. Subjek dari penelitian ini adalah seluruh siswa kelas V SDS Pangkalan Kecamatan Babakan Ciparay yang berjumlah 17 orang. Instrumen dalam penelitian ini adalah soal tes pemahaman konsep matematika materi bangun datar. Hasil penelitian menunjukkan bahwa sebagian besar siswa memiliki kemampuan pemahaman konsep matematika yang rendah pada materi bangun datar dan kesalahan yang dilakukan dalam mengerjakan soal berdasarkan analisis Newman sebagian besar terletak pada kesalahan memahami soal yaitu sebanyak 41,17\%.
\end{abstract}

Kata kunci: Kesalahan Siswa, Bangun Datar, Pemahaman konsep

\section{PENDAHULUAN}

Matematika merupakan salah satu ilmu dasar dalam kehidupan. Matematika memiliki peranan penting dalam kehidupan sehari-hari karena matematika dapat membentuk pola pikir siswa. Pembelajaran matematika merupakan ilmu eksakta yang lebih banyak memerlukan pemahaman dibandingkan dengan hapalan (Suswigi, 2019). Kegiatan pembelajaran yang dilakukan oleh setiap guru lebih menekankan pada hapalan dan mendapatkan jawaban serta menyerahkan jawaban sepenuhnya kepada guru untuk menentukan apakah jawaban benar atau salah, sehingga kemampuan 
pemahaman siswa rendah (Yanti, Melati \& Zanthy, 2019) Salah satu materi yang memerlukan pemahaman adalah materi bangun datar. Bangun datar merupakan materi yang sangat penting karena sangat berkaitan dengan kehidupan sehari-hari. Oleh karena itu diperlukan kemampuan pemahaman yang baik terutama kemampuan memahami konsep pada materi bangun datar.

Pemahaman konsep adalah salah satu aspek penilaian dalam pembelajaran. Penilaian pada aspek pemahaman konsep bertujuan untuk mengetahui sejauh mana kemampuan siswa menerima dan memahami konsep dasar metematika yang telah diterima siswa dalam pembelajaran. Pemahaman konsep di sekolah dasar sangat penting karena dengan penguasaan konsep akan memudahkan siswa dalam mempelajari matematika dan merupakan kunci untuk melanjutkan pelajaran di tingkat berikutnya. Siswa dikatakan telah memahami suatu konsep matematika jika siswa tersebut telah mampu menjelaskan konsep dengan kata-kata sendiri.

Menurut NCTM (Nurjaman \& Sari, 2016) kemampuan pemahaman konsep dapat dicapai dengan indikator sebagai berikut: a) Menyatakan ulang sebuah konsep; b) Mengklasifikasikan objekobjek menurut sifat-sifat tertentu sesuai dengan konsepnya; c) Memberi contoh dan bukan contoh dari konsep; d) Menyajikan konsep dalam berbagai bentuk representasi matematis; e) Mengembangkan syarat perlu atau syarat cukup suatu konsep; f) menggunakan, memanfaatkan, dan memilih prosedur atau operasi tertentu; g) Mengaplikasikan konsep atau algoritma dalam pemecahan masalah matematis.

Pada siswa Sekolah Dasar, dalam memahami pembelajaran masih memerlukan hal-hal yang konkret dimana siswa menggunakan masalah situasi nyata/kontekstual dijadikan sebagai titik awal siswa dalam belajar untuk menopang terlaksananya suatu proses penemuan kembali sehingga secara formal siswa dapat memahami konsep matematika. (Fitriani \& Yuliani, 2016). Isrotun (2014:1) menyatakan bahwa akar penyebab masalah kurangnya pemahaman konsep matematika siswa antara lain: 1) Siswa kurang memikirkan konsep yang telah dipelajari sehingga konsep yang dipelajari tidak bertahan lama, 2) Siswa enggan untuk memahami soal-soal latihan terlebih dahulu dalam mengerjakan soal dan beranggapan bahwa soal tersebut sulit untuk dikerjakan, 3) Siswa sulit untuk mengaplikasikan materi dalam kehidupan sehari-hari. Hal ini sejalan dengan penelitian yang telah dilakukan oleh Yulianingsih, Febrian dan Dwinata (2018) dimana kesalahan yang sistematis dan konsisten terjadi disebabkan oleh tingkat penguasaan materi yang kurang pada siswa.

Pada tingkat Sekolah Dasar, Matematika perlu diberikan membekali mereka dengan kemampuan berpikir logis, analitis, sistematis, kritis dan kreatif serta kemampuan bekerja sama (Yuniarti, Dkk, 2018). Materi pokok geometri merupakan salah satu materi matematika yang sulit dipahami oleh siswa karena keabstrakannya, hal ini dapat dilihat dari hasil penelitian yang dilakukan oleh Sunardi (Yuwono, 2014:961) bahwa dalam mempelajari geometri terdapat beberapa kesalahan dan kesulitan yang dialami siswa yaitu: 1)Salah dalam menyelesaikan soal-soal tentang garis sejajar, 2)Kekeliruan siswa dalam membedakan bangun jajargenjang dan belah ketupat, 3)Kurangnya pemahaman siswa terhadap suatu konsep matematika sehingga berdampak pada hasil belajar yang 
dihasilkan kurang memuaskan dan 4)Kesulitan menggolongkan jenis-jenis segiempat yang mempunyai hubungan sifat-sifat yang sama. Penelitian yang dilakukan Dadang (2018) menyatakan bahwa kemampuan pemahaman dan berfikir kreatif matematik siswa SMP pada materi bangun datar dalam kategori rendah karena dipengaruhi oleh psikologis siswa.

Untuk mencapai pemahaman konsep dalam matematika bukanlah suatu hal yang mudah karena pemahaman siswa terhadap suatu konsep matematika bersifat sangat individual. Setiap siswa mempunyai kemampuan yang berbeda dalam memahami konsep-konsep matematika. Namun demikian menanamkan pemahaman konsep matematis perlu diupayakan demi keberhasilan siswa dalam belajar.Sebagaimana dijelaskan oleh Priyo (dalam Kustiyati 2016: 305) bahwa pemahaman yang tidak mantap akan mengakibatkan siswa mengalami kesulitan dalam menyelesaikan soal-soal matematika.

Penelitian ini dimaksudkan untuk menganalisis kesalahan-kesalahan yang dilakukan siswa pada soal pemahaman konsep bangu datar berdasarkan analisis Newman. Penelitian ini diharapkan dapat memberikan informasi serta gambaran penyebab siswa mengalami kesalahan dalam mengerjakan soal pemahaman konsep matematika sehingga bisa menjadi bahan evaluasi untuk pembelajaran kedepannya. Dengan demikian diperlukan upaya menganalisis kesalahan-kesalahan siswa dalam menyelesaikan masalah soal pemahaman konsep matematika untuk mendeteksi kesulitan belajar siswa sehingga dapat menemukan alternatif pemecahannya dalam menyelesaikan soal materi bangun datar. Pemilihan soal pemahaman konsep merupakan kemampuan mendasar dibandingkan dengan kemampuan penalaran, komunikasi, berfikir kreatif maupun berpikir kritis. Oleh karena itu dilakukan penelitian dengan judul "Analisis kesalahan siswa dalam menyelesaikan soal pemahaman konsep matematika sekolah dasar pangkalan pada materi bangun datar

Penelitian ini bertujuan untuk mengetahui seberapa besar persentase kesalahan siswa menyelesaikan soal metematika materi bangun datar berdasarkan Analisis Newman yang terdiri dari beberapa jenis kesalahan yaitu (1) kesalahan membaca soal (reading error), (2) kesalahan memahami soal (comprehension error), (3) kesalahan transformasi (transformastion error), (4) kesalahan keterampilan proses (process skills error), dan (5) kesalahan penulisan jawaban akhir (encoding error) dan untuk mengetahui kesalahan apa yang paling banyak dilakukan siswa.

Jha (2012), Singh (2010), dan White (2005) memberikan beberapa faktor dan indikator yang menjadi penyebab siswa melakukan kesalahan dalam menyelesaikan soal bentuk uraian yang didasarkan pada prosedur Newman. Adapun tabel factor dan indikator penyebab siswa melakukan kesalahan adalah: 
Tabel 1.

Faktor dan Indikator Penyebab Kesalahan Siswa

\begin{tabular}{|c|c|}
\hline $\begin{array}{l}\text { Faktor Penyebab } \\
\text { kesalahan siswa }\end{array}$ & Indikator \\
\hline reading error & $\begin{array}{l}\text { - Siswa tidak mampu membaca atau mengenali simbol dalam soal. } \\
\text { - Siswa tidak mampu memaknai arti setiap kata, istilah atau simbol } \\
\text { dalam soal. }\end{array}$ \\
\hline comprehension error & $\begin{array}{l}\text { - Siswa tidak memahami informasi apa saja yang diketahui dalam soal } \\
\text { dengan lengkap. } \\
\text { - Siswa tidak memahami apa saja yang ditanyakan dalam soal dengan } \\
\text { lengkap. }\end{array}$ \\
\hline transformation error & $\begin{array}{l}\text { - Siswa tidak mampu membuat model matematis dari informasi yang } \\
\text { didapatkan. } \\
\text { - Siswa tidak mengetahui rumus yang akan digunakan untuk } \\
\text { menyelesaikan soal. } \\
\text { - Siswa tidak mengetahui operasi hitung yang akan digunakan untuk } \\
\text { menyelesaikan soal. }\end{array}$ \\
\hline process skills error & $\begin{array}{l}\text { - Siswa tidak mengetahui prosedur atau langkah-langkah yang akan } \\
\text { digunakan untuk menyelesaikan soal dengan tepat. }\end{array}$ \\
\hline encoding error & $\begin{array}{l}\text { - Siswa tidak mampu menemukan hasil akhir dari soal berdasarkan } \\
\text { prosedur atau langkah-langkah yang telah digunakan. } \\
\text { - Siswa tidak dapat menunjukan jawaban akhir dari penyelesaian soal } \\
\text { dengan benar. } \\
\text { - Siswa tidak dapat menuliskan jawaban akhir sesuai dengan } \\
\text { kesimpulan. }\end{array}$ \\
\hline
\end{tabular}

\section{METODE}

Penelitian ini merupakan penelitian kualitatif yang bertujuan menganalisis kesalahan siswa pada soal pemahaman konsep matematika siswa sekolah dasar pada materi bangun datar. Penelitian kualitatif adalah penelitian yang digunakan untuk meneliti pada kondisi objek alamiah, dimana peneliti merupakan instrunen kunci (Sugiyono, 2005).

Dalam menentukan subjek penelitian ini menggunakan teknik purposive sampling dengan memilih dan memilah subjek yang memenuhi kriteria yang telah ditentukan. Kriteria tersebut adalah siswa yang bermasalah dalam pemahaman konsep matematik. Teknik pengumpulan data menggunakan tes. Instrumen penelitian ini terdiri dari 5 soal berbentuk uraian pada materi bangun datar yang mengacu pada soal tes kemampuan pemahaman konsep matematis sebanyak lima soal dengan waktu selama 60 menit. Subjek dari penelitian ini adalah seluruh siswa kelas V SDS Pangkalan. Sampel dari penelitian ini diambil dari siswa kelas V SDS Pangkalan dengan kemampuan tinggi, sedang dan rendah.

Instrumen yang digunakan dalam penelitian ini berupa soal uraian materi bangun datar yang terdiri dari 5 soal berdasarkan indikator kemampuan pemahaman konse. Adapun Indikator kemampuan pemahaman konsep pada soal yang digunakan sebagai berikut: 


\section{Tabel 2.}

Indikator kemampuan pemahaman konsep pada soal materi bangun datar

\begin{tabular}{|c|c|}
\hline No Soal & Indikator \\
\hline 1. & Mendefinisikan konsep secara tulisan \\
\hline 2. & Mendefinisikan dan mengidentifikasi contoh dan bukan contoh \\
\hline 3. & Mempresentasikan suatu konsep dalam bentuk model,diagram dan simbol \\
\hline 4. & Mengenal syarat yang menentukan suatu konsep. \\
\hline 5. & Menturaturat bentuk resentasi kentuk lainna \\
\hline
\end{tabular}

Setelah didapatkan persentase jawaban responden selanjutnya diberikan penafsiran atau penilaian terhadap hasil penelitian.. Peneliti menggunakan metode penafsiran menurut Arikunto (Kamelta, 2013) seperti tabel 2 berikut :

Tabel 3.

Kategori Nilai Persentase

\begin{tabular}{|l|c|c|}
\hline No. & Persentase Batas & Kategori Penilaian \\
\hline 1. & $0-20 \%$ & Sangat rendah \\
\hline 2. & $21-40 \%$ & Rendah \\
\hline 3. & $41-60 \%$ & Sedang \\
\hline 4. & $61-80 \%$ & Tinggi \\
\hline 5. & $81-100 \%$ & Sangat tinggi \\
\hline
\end{tabular}

\section{HASIL}

Berdasarkan hasil tes uraian hasil pekerjaan 17 siswa dengan menggunakan prosedur Newman diperoleh jenis kesalahan yang beragam yang dilakukan oleh siswa pada soal yang diberikan. Soal yang diujikan terdiri dari lima butir soal pertanyaan pada tabel berikut:

\section{Tabel 6.}

Soal Kemampuan Pemahaman Konsep

\begin{tabular}{|c|c|c|}
\hline No & Indikator & Soal \\
\hline 1. & Mendefinisikan konsep secara tulisan & Segiempat adalah bangun datar yang... \\
\hline 2. & $\begin{array}{l}\text { Mendefinisikan dan mengidentifikasi } \\
\text { contoh dan bukan contoh }\end{array}$ & $\begin{array}{l}\text { 1. Perhatikan nama bangun datar di bawah ini! } \\
\text { - Segiempat } \\
\text { - Persegi panjang } \\
\text { - Segitiga } \\
\text { - Lingkaran } \\
\text { - Segienam } \\
\text { - Belah ketupat } \\
\text { Manakah yang termasuk bangun datar yang } \\
\text { memiliki } 4 \text { sisi? coba gambarkan! }\end{array}$ \\
\hline 3. & $\begin{array}{l}\text { Mempresentasikan suatu konsep } \\
\text { dalam bentuk model,diagram dan } \\
\text { simbol }\end{array}$ & $\begin{array}{l}\text { Sebuah bangun datar } \mathrm{ABCD} \text { dimana } \mathrm{AB} \text { memiliki } \\
\text { panjang } 3 \mathrm{~cm} \text {, sedangkan } \mathrm{CD} 7 \mathrm{~cm} \text {. dimana panjang } \\
\mathrm{BC}=\mathrm{AB} \text { dan panjang } \mathrm{DA}=\mathrm{CD} \text {. Maka terbentuk }\end{array}$ \\
\hline
\end{tabular}


Analisis Kesalahan Siswa Dalam Menyelesaikan Soal Pemahaman Konsep Matematika Sekolah Dasar Pada Materi Bangun Datar, Melisari, Asri Septihani Arphin Chronika, Bunga Permaganti, Yeti Jumiati, Nelly Fitriani

\begin{tabular}{|l|l|l|}
\hline 4. & $\begin{array}{l}\text { Mengubah suatu bentuk representasi } \\
\text { ke bentuk lainnya } \\
\text { datar tersebut! }\end{array}$ & $\begin{array}{l}\text { Pak Wahyu memiliki kebun yang berbentuk seperti di } \\
\text { bawah ini. Disekeliling kebun akan ditanami pohon } \\
\text { dengan jarak antar pohon 1 meter. } \\
\text { a. Berapa banyak pohon yang harus ditanam? } \\
\text { b. Berapa luas kebun yang dimiliki Pak Wahyu ? }\end{array}$ \\
\hline 5. & $\begin{array}{l}\text { Mengenal syarat yang menentukan } \\
\text { suatu konsep. }\end{array}$ & Sebutkan minimal 3 syarat Persegi panjang! \\
\hline
\end{tabular}

Berdasarkan analisis kesalahan Newman, diperoleh hasil kesalahan siswa sebagai berikut:

\section{Kesalahan Membaca Soal}

Tahap kesalahan membaca soal merupakan tahapan dimana paling sedikit siswa melakukan kesalahan. Hal ini dikarenakan bentuk soal mengunakan bahasa Indonesia yang baik dan jelas serta tidak banyak mengandung simbol-simbol. Rata-rata kesalahan yang dilakukan siswa sebesar 7,05\%. Siswa dikatakan melakukan kesalahan membaca jika siswa tidak dapat mengenal/membaca simbolsimbol yang ada pada soal, mengerti makna dari simbol pada soal tersebut atau memaknai kata kunci yang terdapat pada soal tersebut (Rokhimah, 2015). Berikut contoh kesalahan siswa dalam membaca soal pada soal no1.

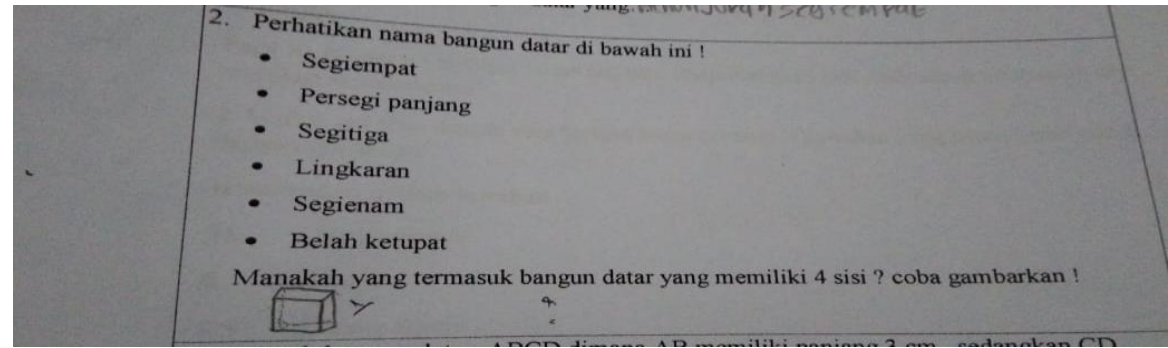

Gambar 1. Contoh kesalahan membaca soal

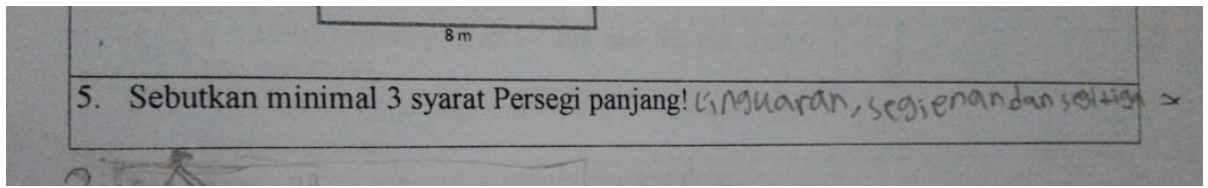

Gambar 2. Contoh Kesalahan Membaca Soal

Gambar 1 merupakan salah satu dari hasil pekerjaan siswa pada soal no 2 yaitu pada indikator mendefinisikan dan mengidentifikasi contoh dan bukan contoh. Pada soal tersebut, siswa memberikan contoh kubus yang bukan merupkan bangun datar meskipun memiliki 4 sisi. Sedangkan pada gambar 2 yang merupakan soal no 5 pada indikator mengenal syarat yang menentukan suatu konsep, terlihat 
pada jawaban siswa ketika ditanyakan syarat persegi panjang, siswa menjawab macam-macam bangun datar. Oleh karena itu, pada soal no 2 dan 5 dikategorikan kesalahan membaca soal.

\section{Kesalahan Memahami Soal}

Pada indikator kesalahan memahami soal, diperoleh persentase sebanyak 41,17\% siswa yang melakukan kesalahan memahami soal. Siswa dikatakan melakukan kesalahan memahami jika siswa tidak mampu menetukan apa yang diketahui dan apa yang ditanyakan (Widodo, 2013) Berikut contoh kesalahan siswa dalam memahami soal :

\section{Segiempat adalah bangun datar yang.. Meuz 9 ta $\sqrt{x}$}

Gambar 3. Contoh Kesalahan Memahami Soal

Berdasarkan hasil pekerjaan siswa yang terlihat pada gambar di atas yaitu soal no1 pada indikator mendefinisikan konsep secara tulisan. Pada gambar menunjukan jawaban siswa yang tidak menjelaskan apa yang ditanyakan. Hal ini disebabkan siswa salah menjawab ketika ditanyakan pengertian segiempat. Siswa diharapakan menjawab pengertian segiempat berdasarkan ciri-cirinya seperti memiliki 4 sisi dan sudut yang sama panjang sehingga terjadi kesalahan memahami soal.

\section{Kesalahan Transformasi}

Pada indikator kesalahan transformasi, siswa yang melakukan kesalahan sebesar 29,41\%. Siswa dikatakan melakukan kesalahan transformasi jika siswa tidak menuliskan metode yang akan digunakan, menuliskan metode yang tidak tepat, atau tidak lengkap, menuliskan metode tapi tidak menuliskan rumus matematik yang diperlukan untuk menyelesaikan soal. Kesalahan transformasi yang dilakukan siswa ditunjukan pada pekerjaan siswa di bawah ini :

3. Sebuah bangun datar $\mathrm{ABCD}$ dimana $\mathrm{AB}$ memiliki panjang $3 \mathrm{~cm}$, sedangkan $\mathrm{CD}$ $7 \mathrm{~cm}$. dimana panjang $B C=A B$ dan panjang $D A=C D$. Maka terbentuk Bangun datar apakah itu ? coba gambarkan bangun datar tersebut! Jor Jor 5 gen Joug

Gambar 4. Contoh Kesalahan Transformasi

Pada gambar 4 menunjukkan salah satu jawaban siswa pada soal no 3 dengan indikator mempresentasikan suatu konsep dalam bentuk model,diagram dan simbol. Berdasarkan hasil pekerjaan siswa yang ditunjukan gambar di atas terlihat siswa tidak menuliskan metode dalam mengerjakan serta jawaban yang diperoleh tidak tepat dan terjadi kesalahan transformasi.

\section{Kesalahan Keterampilan Proses}

Pada indikator keterampilan proses, siswa yang melakukan kesalahan sebesar 16,15\%. Siswa dikatakan mengalami kesalahan keterampilan proses jika siswa melakukan kesalahan dalam komputasi, 
kesalahan konsep, tidak melanjutkan prosedur penyelesaian (macet), atau tidak menuliskan tahapan perhitungan. Pada indikator kesalahan keterampilan proses, tidak terdapat siswa yang melakukan kesalahan ini disebabkan semua siswa Berikut akan ditunjukan pekerjaan siswa yang melakukan kesalahan ketrampilan proses.

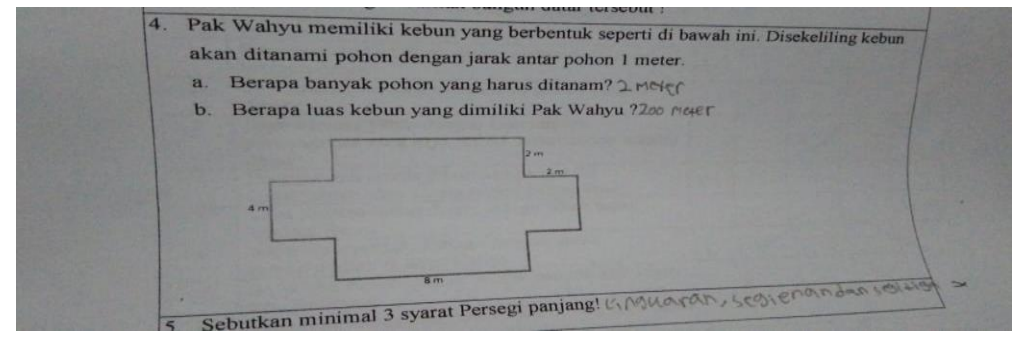

Gambar 5.Contoh Kesalahan Keterampilan Proses

Berdasarkan hasil pekerjaan siswa yang ditunjukan pada gambar di atas terlihat bahwa siswa melakukan kesalahan komputasi yaitu siswa melakukan perhitungan yang salah sehingga dalam penelitian ini siswa dikatakan melakukan kesalahan ketrampilan proses.

\section{Kesalahan Penulisan Jawaban Akhir}

Siswa dikatakan melakukan kesalahan penulisan jawaban akhir jika siswa sudah dapat mengerjakan penyelesaian secara tepat tetapi tidak menuliskan kesimpulan jawaban akhir atau menyimpulkan jawaban akhir yang tidak sesuai dengan konteks soal. Pada indikator kesalahan ini, tidak terdapat jawaban yang menunujkan kesalahan penulisan jawaban akhir disebabkan soal yang diberikan tidak terdapat siswa yang melakukan penyelesaian secara tepat tetapi tidak menuliskan kesimpulan jawaban. Selain itu, soal yang memerlukan proses penyelesaian hanya no 4, sedangkan semua siswa belum bisa memahami penyelesaiannya pada soal tersebut.

Secara umum, kemampuan pemahaman konsep matematis tergolong rendah.. Hal ini dapat terlihat dari tabel Persentase hasil jawaban siswa berdasarkan indikator soal kemampuan pemahaman konsep dibawah ini:

\section{Tabel 4.}

Presentase kemampuan siswa dalam menyelesaikan soal bangun datar berdasarkan indikator

\begin{tabular}{|c|l|r|l|}
\hline No soal & \multicolumn{1}{|c|}{ Indikator } & Persentase & Kategori \\
\hline 1. & Mendefinisikan konsep secara tulisan & $47 \%$ & Sedang \\
\hline 2. & $\begin{array}{l}\text { Mendefinisikan dan mengidentifikasi } \\
\text { contoh dan bukan contoh }\end{array}$ & $54,9 \%$ & Sedang \\
\hline 3. & $\begin{array}{l}\text { Mempresentasikan suatu konsep } \\
\text { dalam bentuk model,diagram dan simbol }\end{array}$ & $36.5 \%$ & Rendah \\
\hline 4. & $\begin{array}{l}\text { Mengubah suatu bentuk representasi ke } \\
\text { bentuk lainnya }\end{array}$ & $20 \%$ & $\begin{array}{l}\text { Sangat } \\
\text { Rendah }\end{array}$ \\
\hline 5. & Mengenal syarat yang menentukan suatu konsep. & $19,1 \%$ & Sedang \\
\hline
\end{tabular}


Berdasarkan hasil yang ditunjukkan pada tabel 4, kemampuan pemahaman konsep siswa dalam menyelesaikan soal bangun datar untuk semua indikator masih rendah. Sampel diperoleh dari siswa berkemampuan tinggi, sedang, dan rendah, dimana data siswa diambil dari traskrip nilai ulangan harian matematika siswa .Berikut transkrip nilai ulangan harian siswa kelas V SDS Pangkalan.

\section{Tabel 5.}

Transkrip Nilai Ulangan harian.

\begin{tabular}{|c|l|c|c|c|c|}
\hline No & Nama & \multicolumn{4}{|c|}{ Nilai Harian } \\
\hline 1 & Syafa & 74 & 65 & 67 & 68,7 \\
\hline 2 & Amel & 69 & 70 & 66 & 68,3 \\
\hline 3 & Dika & 65 & 66 & 65 & 65,3 \\
\hline 4 & Ardi & 70 & 68 & 68 & 68,7 \\
\hline 5 & Cantika & 65 & 67 & 66 & 66,0 \\
\hline 6 & Dapid & 65 & 68 & 66 & 66,3 \\
\hline 7 & Dudi & 85 & 76 & 80 & 80,3 \\
\hline 8 & Erna & 80 & 74 & 75 & 76,3 \\
\hline 9 & Fitria & 67 & 74 & 78 & 73,0 \\
\hline 10 & Gilang & 74 & 70 & 67 & 70,3 \\
\hline 11 & Hilma & 67 & 70 & 66 & 67,7 \\
\hline 12 & Joni & 75 & 76 & 72 & 74,3 \\
\hline 13 & Marcel & 79 & 76 & 80 & 78,3 \\
\hline 14 & Mulyadi & 69 & 71 & 66 & 68,7 \\
\hline 15 & Nathan & 65 & 72 & 65 & 67,3 \\
\hline 16 & Radit & 67 & 70 & 66 & 67,7 \\
\hline 17 & Ria & 65 & 70 & 65 & 66,7 \\
\hline
\end{tabular}

\section{KESIMPULAN}

Berdasarkan hasil penelitian dan pembahasan berdasarkan analisis Newman pada siswa kelas IV SDS Pangkalan pada materi bangun datar diperoleh bahwa (1) Presentase kesalahan membaca soal sebesar 7,05\% dengan kategori sangat rendah, (2) persentase kesalahan memahami soal sebesar 41,17\% dengan kategori sedang, (3) persentase kesalahan transformasi sebesar 29,41\% dengan kategori rendah, (4) persentase kesalahan keterampilan proses sebesar 16,15\% dengan kategori rendah. Maka dapat disimpulkan bahwa kesalahan paling banyak dilakukan siswa kelas IV SDS Pangkalan dalam menyelesaikan soal matematika materi bangun datar berdasarkan Analisis Newman terletak pada kesalahan memahami soal sebanyak 41,17\%, Hal ini disebabkan karena masih rendahnya kemampuan siswa dalam memahami materi bangun datar sehingga banyak siswa lupa dengan apa yang sudah diajarkan. Oleh karena itu, guru sangat berpersan besar dalam memberikan pemahaman kepada siswa dalam menjelaskan materi bukan hanya menyampaikan materi. 
Analisis Kesalahan Siswa Dalam Menyelesaikan Soal Pemahaman Konsep Matematika Sekolah Dasar Pada Materi

\section{DAFTAR PUSTAKA}

Dadang, A., Ramdani, M. (2018). Analisis Kemampuan Pemahaman Dan Berpikir Kreatif Matematika Siswa Mts Pada Materi Bangun Ruang Sisi Datar. Jurnal Cendekia: Jurnal Pendidikan Matematik. Vol (2)2, hal 1-7

Fitriani, N., Yuliani, A.(2016). Analisis Penerapan Pembelajaran Matematika Berbasis Pmri Pada Sekolah Dasar Di Kota Bandung. Jurnal Ilmiah UPT P2M STKIP Siliwangi, Vol (3)1

Kamelta, Edo (2013). Pemanfaatan Internet Oleh Mahasiswa Jurusan Teknik Sipil Fakultas Teknik Universitas Negeri Padang. CIVED, Padang

Isrotun, Umi. (2014). Peningkatan Pemahaman Konsep Matematika Melalui Penerapan Pembelajaran Realistik. Semarang

Nurjaman, A., \& Sari, I. P. (2017). The Effect Of Problem Posing Approach Towards Students' Mathematical Disposition, Critical \&Amp; Creative Thinking Ability Based On School Level. Infinity Journal, 6(1), 69. https://doi.org/10.22460/infinity.v6i1.223

Kustiyati (2016). Problematika Pembelajaran Matematika Materi Bangun Ruang Sisi Lengkung di SMP dan Alternatif Pemecahannya.

Minarti, ED. (2019). Analisis Kesalahan Siswa SMK Dalam Menyelesaikan Soal Kecakapan Matematis Pada Materi Bangun Ruang. Jurnal Mosharafa, Vol 8(3), hal 365-376.

Rokhimah, S. (2015). Analisis Kesalahan Siswa Dalam Menyelesaikan Soal Cerita Matematika Materi Aritmatika Sosial Kelas VII Berdasarkan Prosedur Newman. Tersedia: https://www.jurnal-online.um.ac.id (diakses 10 januari 2020, pukul 15:36).

Sugiyono. (2013). Metode Penelitian Pendidikan: Pendekatan Kuantitatif dan Kualitatif, dan R\&D. Bandung: Alfabeta.

Suswigi, Zanthy, S. (2019) Kemampuan Pemahaman Matematik Siswa MTS Di Cimahi Pada Materi Persamaan Garis Lurus. Jurnal Cendekia: Jurnal Pendidikan Matematika, (3)1, 40-46

Widodo, S. A. (2013). Analisis Kesalahan Dalam Pemecahan Masalah Divergensi Tipe Pembuktian Pada Mahasiswa Matematika. Jurnal Pendidikan Dan Pengajaran. 46(2), hal: 106-113.

Yanti, N.R., Melati, A.S., \& Zanthy, L.S (2019). Analisis Kemampuan Pemahaman Dan Kemampuan Komunikasi Matematis Siswa Smp Pada Materi Relasi Dan Fungsi. Jurnal Cendekia: Jurnal Pendidikan Matematik. Vol(3)1, Hal 209-219

Yuniarti, N., dkk (2018). Hubungan Kemampuan Komunikasi Matematis Dengan Self Esteem Siswa Smp MelaluiPendekatan Contextual Teaching And Learning Pada Materi Segiempat. JNPM (Jurnal Nasional Pendidikan Matematika) Vol. 1(2), Hal.62

Yuwono, Ridlo Muhammad. (2014). Eksperimentasi Model Pembelajaran Kooperatif Tipe Teams Games Tournament Dengan Strategi Peta Konsep Pada Materi Segiempat Ditinjau Dari 
Kemampuan spasial Peserta Didik. Jurnal Elektronik Pembelajaran Matematika. Vol.2. No.9. ISSN 2339-16

Yulianingsih, Alifah., Febrian \& Dwinata, Alona. (2018). Analisis Kesalahan Konsep Pecahan pada Siswa Kelas VII A SMP Negeri 13 Satu Atap Tanjungpinang. Jurnal Mosharafa, 7(1), 85-94. 